\title{
とうもろこし，イネ科乾草，アルファルファヘイキューブと 比較したビートパルプの乳牛における産乳性
}

\author{
佐渡谷裕朗・佐藤 忠・田中勝三郎・岡本明治* \\ 日本甜菜製糖株式会社総合研究所，帯広市 080 \\ *帯広畜産大学，帯㕕市 080
}

(1994. 7. 8 受付)

\begin{abstract}
要 約 款類おょび粗飼料をビートパルプ（BP）で代替する時の乳牛の産乳性を换討するため，とう もるこし(実験 1)，イネ科乾草（実験 2)，アルファルファヘイキューブ（実験 3）を用いて比較した。 実験 1 はとうもろこしとBP の配合割合を $100 ： 0 ， 50 ： 50 ， 0 ： 100$ とした 3 種の配合飼料を用いて泌乳 試験を行なっった. 実験 2 と 3 は BP の粗飼料代替勃果を検討するあのであり, 実験 2 はイネ科乾草と BP の給与比率を $100: 0,50: 50,0: 100$ とし, 実験 3 は補助的に給与するアルファルファへイキューブ （ALC）をBP で全量置き換元泌乳試験を行なった，実験 1 に扔いて，配合泀料中に含まれるとうあるこ しの $50 \%$ BP に代替すると，乳量はやや低くなるが乳脂率はやや高まる傾向にあった，そのため，4\% 脂肪補正孚 (4\% FCM)，固形分補正乳（SCM）はほぼ等しく，乳牛に給与するとうむるこしの $50 \%$ は $\mathrm{BP}$ で代替できるもとの考元られた，実験 2 では，BP 給与により乾物摄取量，乳量，乳蛋白質率，無脂 固形分率はイネ科乾草給与より高くなり, 産乳効果は BPがイネ科乾草上り優机ているあのと考えられ た。 また，乳脂率はBPとイネ科乾草の併給により高まる傾向にあったＡＡLC と比較した結果，乾物摄 取量に差はみられなかったが, 乳量, $4 \% \mathrm{FCM}, \mathrm{SCM}$ は $\mathrm{BP}$ 給与により有意 $(\mathrm{P}<0.01)$ に高まる傾向に あった。ルーメン内揮発性脂肪酸 (VFA) 含量は $\mathrm{BP}$ 給与に上って ALC 給与上り有意に $(\mathrm{P}<0.01)$ 高 くなったが、VFA 組成に差はみられなかった。
\end{abstract}

日畜会報, 66 (6) : 540-547, 1995

テンサイより糖を抽出した残さであるビートパルプ (BP)は，わが国で広く使われている乳牛用飼料である. $\mathrm{BP} の$ 栄養価を穀類およびイネ科乾草 (HAY) と比較す ると,TDN 含量は穀類に近く繊維成分は粗飼料に近い ことから、BPはHAY と穀類の両者の効果を合わせ持 つ飼料であると考えられる。しかし，BPの産乳効果に ついての徉米の報告は大麦と比較した研究が多く2,4,6), ようもろこし(CO) を主原料とした大量の配合飼料を給 与している現在の飼養実熊に適合しない，また，粗飼料 と比較検討した報告も少ない。

そこで本報告は BPで CO, HAYおよびアルファル ファヘイキューブ（ALC）を代替した飼料を給与した場 合の乳牛の産乳性を比較検討した。

\section{材料および方法}

供試動物：実鋁 $1 ， 2$ では，分婏後 75 日以上経過し
たホルスタイン種釈牛を 12 頭, 実験 3 では 8 頭を供試 Lた.

試験設計：実験 $1 ， 2$ は 1 区 4 頭の $3 \times 3$ ラテン方格 法により行なった。実験 3 は，1区 4 頭の 2 重反転法 ${ }^{12)}$ により行なった。 試験期間は 1 期 21 日間で行なった。

供試飼料と飼料給与方法: 奏験 1 では配合飼料中の COをBP で代替し，産乳性を検討した，用いた配合飼料 は，表 1 に示した配合割合で直径 $6 \mathrm{~mm}$ のペレットに加 エしたものであり，BP の配合割合を $0,25,50 \% の 3$ 水 準（BP0， BP 25，BP 50）とした.コーンサイレージ （CS）は早生種黄熟期に刈り取り調製したもの, HAY は チモシー 1 番草を用いた，各配合飼料は試験開始前の乳 量, 乳脂率より算出した $4 \%$ 脂肪補正乳 (4\% FCM) の $45 \%$ 相当量を給与し, CS は供試牛に一律 $15 \mathrm{~kg}$ 給与し た. 各配合飼料执よび CS は 6 時 30 分, 13 時 30 分, 16 時 30 分の 3 回に分けて給与した. HAY は供試牛が配合 


\section{ビートパルプの産乳性}

飼料，CS を摄取した後に残飼がでるように給与した。 また，各実験上も，BP は日本甜菜製糖(株)芽室製糖所 で糖分を抽出した残さに製糖副産液（乾物 $50.4 \%$ ，粗蛋 白質 $14 \%$ ） 10\%添加後乾燥し， $60 \mathrm{~kg}$ に生縮加工した ものを粗砕して供武した。

実験 2 ではHAYをBPで代替した場合の産釈性を検 討した，配合飼料は市販配合飼料（原物中粗蛋白 $23 \%$ ， TDN74\%)，CSは早生種黄熱期に刈り取り調製したも の, HAY は于モシー 1 番草, BP は韦験 1 と同様のもの を用いた。配合飼料は試験開始前の乳量，乳脂率より算 出した $4 \% \mathrm{FCM}$ の $33 \%$ 相当量を， $\mathrm{CS}$ は供試牛に一律 $15 \mathrm{~kg}$ を実険 1 と同様に 3 回に分けて給与した。配合飼 料，CS を供試牛が摄取した後，HAY，HAYとBP 同 量ずつおよび BP を残飼がでるように給与する3区を設 け，それぞれ $\mathrm{H}, \mathrm{H}+\mathrm{B} 2, \mathrm{~B} 2$ とした。

実騃 3 では ALCとBP の産乳性を比較検討した。配 合飼料，CS，BP は実験 2 と同様のものを用い, HAY は チモシー1番草を用いた．ALC は市販品を用いた，配合 飼料は試験開始前の $4 \% \mathrm{FCM} の 33 \%$ 相当量を， CS は 試験開始前の乳量，乳脂率，体重加ら日本飼荃標準 ${ }^{10)}$
より求めた乾物要求量の $20 \%$ を給与した，ALCおよび BP は乾物要求眰の $20 \%$ を給与し，それぞれ ALC3 およ び B3 とした，配合飼料，CS，ALC および BP は実験 1 と同様に 3 回に分けて給与した。また，HAYの給与量 および給与方法は実験 1 と同様とした。

供試牛の管理方法：10時から13時まではパドック で運動させ，そ机以外はスタンチョンに係留した。水は 自由飲水させた，㨦乳は 6 時，17 時の 2 回振乳とした。 乳冒は各期の後半 7 日間測定し，サンプルを採取した。 体重は各期の最終 3 日間测定した，奏験 3 では，午前 10 特に経口的に第 1 胃内容液を採取した.

分析方法：乳成分の测定は近赤外線牛乳分析器(ミ ルコスキャン 104 型）により行なった。 ベクチンの分析 はPHATAK ${ }^{11)}$ の方法に準じて行なった。第 1 胃内容液は 採取後直ちに pHを測定し，1000Gで 10 分間遠心した 後, 揮発性脂肪酸 (VFA) をガスクロマトグラフにより 定量した。

\section{結果}

実験 1：供試飼料の化学成分を表 1に示した，調製

Table 1. Ingredient and chemical composition of concentrate mixture, hay and corn silage in Expt. 1

\begin{tabular}{|c|c|c|c|c|c|}
\hline & \multicolumn{3}{|c|}{ Concentrate mixture } & \multirow{2}{*}{ Hay } & \multirow{2}{*}{ Corn silage } \\
\hline & $\mathrm{BP} 0$ & $\mathrm{BP} 25$ & BP 50 & & \\
\hline Ingredient $t^{13}, \%$ & & & & . & \\
\hline Beet pulp & 0 & 25.0 & 50.0 & & \\
\hline Corn grain, ground & 50.0 & 25.0 & 0 & & \\
\hline \multicolumn{6}{|l|}{ Chemical composition } \\
\hline DM, \% & 85.3 & 86.4 & 86.4 & 88.6 & 28.7 \\
\hline $\mathrm{CP}$ & 23.9 & 24.2 & 23.9 & 5.9 & 7.6 \\
\hline $\mathrm{NDF}$ & 28.9 & 32.9 & 41.8 & 75.3 & 49.4 \\
\hline $\mathrm{ADF}$ & 10.6 & 12.2 & 18.4 & 39.7 & 27.8 \\
\hline Hemicellulose & 18.3 & 20.7 & 23.4 & 35.6 & 21.6 \\
\hline $\mathrm{NFC}^{22}$ & 37.2 & 32.7 & 23.3 & 13.3 & 34.7 \\
\hline Pectin & 11.5 & 13.9 & 15.7 & 2.2 & 8.4 \\
\hline $\mathrm{Ca}$ & 1.04 & 1.09 & 1.23 & 0.42 & 0.14 \\
\hline $\mathrm{P}$ & 0.44 & 0.44 & 0.43 & 0.09 & 0.14 \\
\hline $\mathrm{TDN}^{3)}$ & 87.9 & 83.6 & 79.8 & 57.9 & 69.0 \\
\hline
\end{tabular}

1) The ingredient composition of concentrate mixture is all equal except beet pulp and corn grain. Each concentrate mixture containd wheat $4.7 \%$, soybean meal $29.0 \%$, rape seed meal $1.5 \%$, rice bran $0.7 \%$, raw rice bran $2.0 \%$, screening pellet $1.9 \%$, guluten feed $3.0 \%$, molasses $4.5 \%$, salt $0.7 \%$, calcium carbonate $1.0 \%$, tricalcium phosphate $1.0 \%$.

2) $\mathrm{NFC}$ : nonfiber carbohydrate $=\mathrm{DM}-(\mathrm{CP}+$ ether extract + ash $+\mathrm{NDF})$

${ }^{3)}$ Concentrate mixture : calculated from Standard Tables of Feed Composition in Japan (1987) $)^{9)}$. Hay and corn silage : calculated from publication by HOKUNOUKAI ${ }^{1)}$ 
した各配合飼料の粗蛋白質，カルシウム $(\mathrm{Ca})$ ，リン $(\mathrm{P})$ 含量はほぼ等しい値であった，中性书よび酸性デター ジェント織維（NDF， ADF），ペクチン含堅はBP の配 合割合が增加するにつれ高くなったが，非瀻維性炭水化 物 (NFC) 执ょびTDN 合量は低くなった。

表 2 に供武動物の䬰料，各栄養成分の摄取量阽よび乳 症，乳成分を示した，供誠飼料間での乾物および粗蛋白 質摄取量に差はみられなかっった NDF, ADF，へミセル ロース，ペクチン摄取量は BP の配合割合が高まるにつ れて增加する傾向にあった．ADF执よびへミセルロー 不摄取量は BP 0 抢よび BP 25 之 BP 50 の間 $(\mathrm{P}<0.05)$ に, ペクチン摄取量は各試験区間に有意な差 $(\mathrm{P}<0.01)$ がみられた。一方, NFC，TDN 摄取量は BP の配合割合 の上昇にともない滅少する傾向にあり，NFC 撕取量は 試験区間に有意な差 $(\mathrm{P}<0.01)$ がみられた。

乳量, 乳蛋白質率, 無脂固形分（SNF）率はとうもろ
こしの配合割合が高いほじ高くなる傾向にあったが、試 験区間に有意な差はみられなかった。乳脂率は BP 25 が 最高人， $4 \% \mathrm{FCM}$ ，固形分補正乳（SCM）は $\mathrm{BP} 0$ 上 BP 25 が BP 50 上り高かったが，これらに有意な差はみ られなかった。

実験 2：供試飼料の化学成分を表 3 に示した. HAY と BP の成分を比較すると, HAY は NDF, ADF 含量が 高く，粗蛋白質， NFC，ペクチン，TDN 含量が低加っ た。

表 4 亿乾物, 各栄盖成分の摄取量お上び乳量, 乳成分 を示した。配合飼料招よびCS の乾物摃取量峙各試験区 間に差はみられなかった。し加し，H の総乾物摄取量は $\mathrm{H}+\mathrm{B} 2$ 抢上び B 2 に比べて低く，有意な差 $(\mathrm{P}<0.05)$ が みられた。 また, 粗蛋白質, へミセルロース, ペクチン, $\mathrm{TDN}$ 摄取量は各試験区間に, ADF 摄取量は $\mathrm{B} 2$ と $\mathrm{H}$ 間 に有意な差 $(\mathrm{P}<0.05)$ がみられた。

Table 2. Feed intake and milk production of dairy cows in Expt. 1

\begin{tabular}{lccc}
\hline & BP 0 & BP 25 & BP 50 \\
\hline DMI, kg/d & & & \\
Concentrate & $10.4 \pm 2.2$ & $10.4 \pm 2.2$ & $10.4 \pm 2.2$ \\
Hay & $5.1 \pm 0.7$ & $4.9 \pm 0.7$ & $5.0 \pm 0.7$ \\
Corn silage & $4.2 \pm 0.3$ & $4.2 \pm 0.3$ & $4.2 \pm 0.3$ \\
Total & $19.7 \pm 2.9$ & $19.5 \pm 2.8$ & $19.6 \pm 2.8$ \\
Intake, kg/d & & & \\
CP & $3.1 \pm 0.6$ & $3.1 \pm 0.6$ & $3.1 \pm 0.6$ \\
NDF & $8.9 \pm 1.1$ & $9.1 \pm 1.1$ & $10.1 \pm 1.3$ \\
ADF & $4.4 \pm 0.5^{\mathrm{b}}$ & $4.5 \pm 0.5^{\mathrm{b}}$ & $5.2 \pm 0.6^{\mathrm{a}}$ \\
Hemicellulose & $4.5 \pm 0.6^{\mathrm{b}}$ & $4.6 \pm 0.6^{\mathrm{b}}$ & $4.9 \pm 0.7^{\mathrm{a}}$ \\
NFC & $6.1 \pm 0.9^{\mathrm{A}}$ & $5.6 \pm 0.8^{\mathrm{B}}$ & $4.6 \pm 0.6^{\mathrm{C}}$ \\
Pectin & $1.7 \pm 0.3^{\mathrm{C}}$ & $1.9 \pm 0.3^{\mathrm{B}}$ & $2.1 \pm 0.4^{\mathrm{A}}$ \\
TDN & $14.9 \pm 0.3$ & $14.4 \pm 2.1$ & $14.1 \pm 2.0$ \\
BW, kg & $623 \pm 48$ & $627 \pm 51$ & $630 \pm 63$ \\
Milk yield, kg/d & $25.6 \pm 5.3$ & $25.1 \pm 4.7$ & $24.9 \pm 5.7$ \\
Milk fat, \% & $3.68 \pm 0.42$ & $3.82 \pm 0.49$ & $3.72 \pm 0.36$ \\
Milk protein, \% $_{\text {SNF }}^{2>} \%$ & $3.09 \pm 0.18$ & $3.07 \pm 0.12$ & $3.05 \pm 0.19$ \\
$4 \% \mathrm{FCM}^{3)}, \mathrm{kg} / \mathrm{d}$ & $8.80 \pm 0.24$ & $8.75 \pm 0.24$ & $8.72 \pm 0.29$ \\
SCM $^{4}, \mathrm{~kg} / \mathrm{d}$ & $24.4 \pm 4.7$ & $24.5 \pm 5.2$ & $23.6 \pm 4.7$ \\
\hline
\end{tabular}

Means $\pm S D$

Means within the same row with different superscripts were significantly different : A. B.C $; P<0.01$, a, $; P<0.05$.

1) NFC : nonfiber carbohydrate $=\mathrm{DM}-(\mathrm{CP}+$ ether extract + ash $+\mathrm{NDF})$

2) SNF : solids-not-fat

3) $4 \%$ FCM : $4 \%$ fat corrected milk

4) SCM : solids-corrected milk 


$$
\text { ビートパルプの産笔性 }
$$

Table 3. Chemical composition of concentrate mixture, hay, corn silage and beet pulp in Expt. 2

\begin{tabular}{lcccc}
\hline \hline & $\begin{array}{c}\text { Concentrate } \\
\text { mixture }\end{array}$ & Corn silage & Hay & Beet pulp \\
\hline DM, \% & 85.6 & 22.9 & 91.1 & 84.8 \\
\cline { 2 - 5 } & 25.9 & 8.6 & 5.8 & 11.3 \\
NDF & 19.7 & 54.6 & 74.3 & 60.8 \\
ADF & 10.7 & 33.6 & 43.6 & 30.7 \\
Hemicellulose & 9.0 & 21.0 & 30.7 & 30.1 \\
NFC & 43.2 & 27.5 & 12.3 & 19.9 \\
Pectin & 11.5 & 7.0 & 4.2 & 17.2 \\
Ca & 1.27 & 0.22 & 0.31 & 0.61 \\
P & 0.81 & 0.22 & 0.19 & 0.11 \\
TDN $^{2)}$ & 84.1 & 64.6 & 52.2 & 74.6 \\
\hline
\end{tabular}

1) NFC : nonfiber carbohydrate $=\mathrm{DM}-(\mathrm{CP}+$ ether extract + ash $+\mathrm{NDF})$

2) Concentrate mixture and beet pulp : calculated from Standard Tables of Feed Composition in Japan $(1987)^{9)}$. Hay and corn silage: calculated from publication by HOKUNOUKAI"

乳量书よび乳脂率を除く乳成分は B2 が他の 2 区より も高い傾向を示し，乳蛋白質率では B 2 上 $\mathrm{H}$ 間に有意な 差 $(\mathrm{P}<0.05)$ がみられた，乳脂率は $\mathrm{H}+\mathrm{B} 2$ が高い傾向 にあったが，有意な差ではなかった。

実験 3：供試飼料の化学成分を表 5 に示した. ALC は BPに比べ，粗蛋白質，ADF， Ca，P含量が高く， $\mathrm{NDF}, \mathrm{NFC}, \mathrm{TDN}$ 含量が低い傾向にあった。

表 6 亿乾物および各栄養成分の摄取量を示した，両区 の乾物摄取量に差はみられなかったが，粗蛋白質， $\mathrm{ADF}$ 摂取量は ALC3が，ヘミセルロース，NFC，ペクチン， TDN 撖取量は B 3 が高く，こ㧈らに有意な差 $(\mathrm{P}<0.01)$ がみられた。

乳量, 乳成分书よびルーメン内VFA 組成在表 7 に示 した。乳量， $4 \% \mathrm{FCM}, \mathrm{SCM}$ は $1 \%$ 水準で，SNF 率は $5 \%$ 水準で有意にB 3 が高かった。

第 1 胃内容液の $\mathrm{pH}$ はB 3 が低く, VFA 総量は ALC 3 低く、これらに有意な差 $(\mathrm{P}<0.01)$ がみられた。し 功、VFAに占める各酸のモル比に差はるられなかっ た.

\section{考察}

実験 1 では $\mathrm{CO}$ と BP の比率を変えて調製した配合飼 料を給与し，それらの産乳性について比较した，乳量は BP 0 が BP 25 および BP 50 よりやや高い傾向を示した が，これは BP 0 の TDN 摂取量が BP 25 および BP 50 より多くなったためと考えられた。
また、BP 0 とP 50 の乳脂率にはほとんど差がみられ ず, BP 25 が最も高い值を示した。この原因として, BP 0 の乾物中 ADF 含量が $22 \%$ で乳脂率低下をむたらす飼 料ではなっだ)ことが考えられた。

日本標準飼料成分表 ${ }^{9}$ に上り各区の TDN 摄取量老計 算すると, BP0が BP 25 より高い。しかし，4\% FCM お よび SCMはBP 0 と BP 25 に差はみられないことから， 洤厚飼料として給与する CO の $50 \%$ は BP で代替でき るものと推察された。

実験 2 ではBP と HAY の給与割合を変更して，その 産乳効果を比較した。乾物摄取量は $\mathrm{B} 2$ が $\mathrm{H}$ 上り有意に 高かったがここ机はBP の NDF 含量がHAYより低い ために，全飼料中の NDF 含量が $\mathrm{H}$ に比べて低くなった

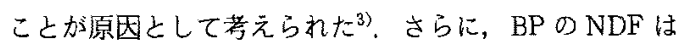
HAY の NDFより分解速度が速い7)ことあ乾物摄取量 を高省一区之推察された。

また，乳量およひ乳蛋白質率は B2 が試験区間で最む 高小㑯向を示したが，そ扎 BP の NFC，TDN 含量か HAY よりも高いことが原因と考えられ，BPの産乳性は HAYより屯優れていることが示唆された。

一方，乳脂率は B 2 と $\mathrm{H}$ の間に差がなかったことか ら、摄取乾物中の BP の割合が $38 \%$ 程度であっても乳脂 率に影響せず， BP はルーメンの恒常性を保つ粗飼料的 効果も有するものと考えられた。

実験 3 ではBPとALC給与による産乳性を比較し た，BP，ALCを除く供試飼料の摂取量はほぼ同量で 
佐渡谷 $\cdot$ 佐藤・田中・岡本

Table 4. Feed intake and milk production of dairy cows in Expt. 2

\begin{tabular}{|c|c|c|c|}
\hline & $\mathrm{H}$ & $\mathrm{H}+\mathrm{B} 2$ & B 2 \\
\hline \multicolumn{4}{|l|}{ DMI, kg/d } \\
\hline Concentrate & $7.2 \pm 1.1$ & $7.2 \pm 1.1$ & $7.2 \pm 1.1$ \\
\hline Corn silage & $3.4 \pm 0.0$ & $3.4 \pm 0.0$ & $3.4 \pm 0.0$ \\
\hline Hay & $5.7 \pm 0.8$ & $3.0 \pm 0.6$ & \\
\hline Beet pulp & & $3.3 \pm 0.4$ & $6.5 \pm 0.9$ \\
\hline Total & $16.3 \pm 1.7^{\mathrm{b}}$ & $16.8 \pm 1.9^{\mathrm{a}}$ & $17.1 \pm 1.9^{\mathrm{a}}$ \\
\hline \multicolumn{4}{|l|}{ Intake, $\mathrm{kg} / \mathrm{d}$} \\
\hline $\mathrm{CP}$ & $2.5 \pm 0.3^{c}$ & $2.7 \pm 0.4^{\mathrm{b}}$ & $2.9 \pm 0.4^{a}$ \\
\hline NDF & $7.5 \pm 0.7$ & $7.5 \pm 0.8$ & $7.3 \pm 0.7$ \\
\hline $\mathrm{ADF}$ & $4.8 \pm 0.5^{b}$ & $4.4 \pm 0.5^{\mathrm{ab}}$ & $3.9 \pm 0.4^{a}$ \\
\hline Hemicellulose & $2.7 \pm 0.3^{c}$ & $3.1 \pm 0.3^{b}$ & $3.4 \pm 0.4^{\mathrm{a}}$ \\
\hline $\mathrm{NFC}^{1)}$ & $4.7 \pm 0.5$ & $5.1 \pm 0.6$ & $5.3 \pm 0.6$ \\
\hline Pectin & $1.3 \pm 0.1^{\mathrm{c}}$ & $1.7 \pm 0.2^{b}$ & $2.2 \pm 0.3^{\mathrm{a}}$ \\
\hline TDN & $11.2 \pm 1.2^{c}$ & $12.2 \pm 1.4^{\mathrm{b}}$ & $13.1 \pm 1.5^{\mathrm{a}}$ \\
\hline $\mathrm{BW}, \mathrm{kg}$ & $597 \pm 51$ & $595 \pm 53$ & $593 \pm 56$ \\
\hline Milk yield, $\mathrm{kg} / \mathrm{d}$ & $21.4 \pm 3.4$ & $22.7 \pm 4.5$ & $23.5 \pm 4.7$ \\
\hline Milk fat, $\%$ & $3.79 \pm 0.45$ & $3.87 \pm 0.41$ & $3.82 \pm 0.67$ \\
\hline Milk protein. \% & $2.98 \pm 0.22^{\mathrm{b}}$ & $3.08 \pm 0.20^{\mathrm{ab}}$ & $3.15 \pm 0.20^{\mathrm{a}}$ \\
\hline $\mathrm{SNF}^{23}, \%$ & $8.66 \pm 0.25$ & $8.81 \pm 0.21$ & $8.88 \pm 0.24$ \\
\hline $4 \% \mathrm{FCM}^{3)}, \mathrm{kg} / \mathrm{d}$ & $20.7 \pm 3.1$ & $22.2 \pm 4.4$ & $22.6 \pm 3.8$ \\
\hline $\mathrm{SCM}^{4)}, \mathrm{kg} / \mathrm{d}$ & $20.5 \pm 2.9$ & $22.2 \pm 4.2$ & $22.7 \pm 3.8$ \\
\hline
\end{tabular}

Means \pm SD

Means within the same row with different superscripts were significantly different $: a, b, c ; P<0.05$.

1) NFC : nonfiber carbohydrate $=\mathrm{DM}-(\mathrm{CP}+$ ether extract + ash $+\mathrm{NDF})$

2) SNF : solids-not-fat

3) $4 \% \mathrm{FCM}: 4 \%$ fat corrected milk

4) $\mathrm{SCM}$ : solids-corrected milk

あったことから，乳量，乳成分に示された差は， BP と ALCに含ま机る成分の差が影響しているあの之考えら れた．各栄養成分の摄取量を見ると，乾物摄取量は両者 に差がみられないが，B 3 はペクチン, ヘミセルロース， TDN の提取量が多く，ALC 3 は粗蛋白質, ADF の摄取 量が多い，すなわち，B 3 に扔いて有意に䝮取量の高 かったペクチンとへミセルロースが乳量，SNF率，4\% FCM および SCMに影響したものと推察された。

さらに,これらのペクチン, ヘミセルロース掑取量の 差はルーメン内発醉にも影響し，特に発醉分解の速いペ クチン摄取量が多いB３においてVFA 総量を有意に高 める発醉がなされたと考えられた。

このように，BP は牧草に比べてより消化されやすい 炭水化物を含有し，毫類のようなエネルギー供給効果と 乾牧草のようなルーメン発醉を正常に保つ機能を合わせ
持つ有用な飼料資源であると考元られた，また，飼料の ルーメン内発醉特性をインビトロを用いて評価し，BP の発醇特性における $\mathrm{pH}$ の变化は豰類に近く, プロピオ ン酸/酶酸比は粗飼料に近いと報告した根川ら ${ }^{5}$ の評佂 ともほぼ一票すると思われた。

以上，BP で穀類あるいは粗飼料を代替したときの乳 牛の産乳性について考察したが，BP で大麦を代替した 場合, VFA と乳量，乳脂率に差がみられなかった報 告26) ああり，COを用いた本成績と一致しない，これら の報告においては乳量水準, 給与飼料構成, 試験条件な どが異なり，どの要因が関与しているのかは不明であ る. しかし，本試験結果加ら得られたように，BP の飼料 としての特性は乳牛に給与する $\mathrm{CO} の 50 \%$ はP で代 替でき, HAY あるいは ALCのような粗飼料よりも産 乳性が高く，粗飼料と濃厚飼料の中間的な性質を有する 


$$
\text { ビートパルプの産乳性 }
$$

Table 5. Chemical composition of concentrate mixture, corn silage, hay, alfalfa hay cube and beet pulp in Expt. 3

\begin{tabular}{lccccc}
\hline \hline & $\begin{array}{c}\text { Concentrate } \\
\text { mixture }\end{array}$ & $\begin{array}{c}\text { Corn } \\
\text { silage }\end{array}$ & Hay & $\begin{array}{c}\text { Alfalfa } \\
\text { hay cube }\end{array}$ & Beet pulp \\
\hline DM, \% & 86.0 & 22.3 & 92.3 & 87.7 & 85.3 \\
\cline { 2 - 6 } CP & 25.4 & 8.7 & 7.8 & 17.6 & 11.6 \\
NDF & 18.3 & 50.3 & 76.3 & 46.2 & 51.1 \\
ADF & 11.4 & 32.2 & 44.2 & 34.9 & 27.7 \\
Hemicellulose & 6.9 & 18.1 & 32.1 & 11.3 & 23.4 \\
NFC & 45.6 & 32.5 & 7.2 & 24.5 & 29.6 \\
Pectin & 11.8 & 7.8 & 3.0 & 13.2 & 21.5 \\
Ca & 1.32 & 0.22 & 0.27 & 1.47 & 0.62 \\
P & 0.84 & 0.22 & 0.27 & 0.22 & 0.15 \\
TDN $^{2)}$ & 81.8 & 65.4 & 53.6 & 59.1 & 74.6 \\
\hline
\end{tabular}

1) NFC : nonfiber carbohydrate $=\mathrm{DM}-(\mathrm{CP}+$ ether extract + ash $+\mathrm{NDF})$

${ }^{2)}$ Concentrate mixture, alfalfa hay cube and beet pulp : calculated from Standard Tables of Feed Composition in Japan (1987) $)^{9}$. Hay and corn silage : calculated from publication by HOKUNOUKAI ${ }^{12}$

Table 6. Feed intake of dairy cows in Expt. 3

\begin{tabular}{|c|c|c|}
\hline & ALC 3 & B 3 \\
\hline \multicolumn{3}{|l|}{ DMI, kg/d } \\
\hline Concentrate & 7. $2 \pm 1.1$ & $7.2 \pm 0.9$ \\
\hline Corn silage & $3.7 \pm 0.4$ & $3.7 \pm 0.3$ \\
\hline Hay & $3.6 \pm 0.5$ & $3.6 \pm 0.4$ \\
\hline Alfalfa hay cube & 4. $3 \pm 0.4$ & \\
\hline Beet pulp & & $4.2 \pm 0.3$ \\
\hline Tớtal & 18. $9 \pm 2.4$ & $18.7 \pm 1.8$ \\
\hline \multicolumn{3}{|l|}{ Intake, $\mathrm{kg} / \mathrm{d}$} \\
\hline $\mathrm{CP}^{* *}$ & 3. $2 \pm 0.4$ & $3.0 \pm 0.4$ \\
\hline NDF & $7.8 \pm 0.8$ & $8.1 \pm 0.8$ \\
\hline $\mathrm{ADF}^{* *}$ & $5.5 \pm 0.7$ & $4.9 \pm 0.5$ \\
\hline Hemicellulose $e^{* *}$ & $2.5 \pm 0.3$ & $3.2 \pm 0.3$ \\
\hline $\mathrm{NFC}^{1) * *}$ & $5.7 \pm 0.7$ & $5.9 \pm 0.7$ \\
\hline Pectin & $1.8 \pm 0.2$ & $2.1 \pm 0.3$ \\
\hline $\mathrm{TDN}^{* *}$ & $12.9 \pm 1.6$ & $13.6 \pm 1.5$ \\
\hline $\mathrm{BW}, \mathrm{kg}$ & $630 \pm 28$ & $630 \pm 30$ \\
\hline
\end{tabular}

Means $\pm S D$

1) NFC : nonfiber carbohydrate $=\mathrm{DM}-(\mathrm{CP}+$ ether extract+ash + NDF)

** indicate statistical significances between ALC 3 and $\mathrm{BP} 3(\mathrm{P}<0.01)$

Table 7. Milk production and VFA concentration in rumen of dairy cows in Expt. 3

\begin{tabular}{lcc}
\hline & ALC 3 & B3 \\
\hline Milk yield, kg/d** & $22.4 \pm 4.0$ & $23.5 \pm 4.3$ \\
Milk fat, \% & $3.55 \pm 0.30$ & $3.62 \pm 0.26$ \\
Milk protein, \% & $2.82 \pm 0.16$ & $2.88 \pm 0.17$ \\
SNF $^{1)}, \% *$ & $8.39 \pm 0.30$ & $8.51 \pm 0.19$ \\
$4 \% \mathrm{FCM}^{2)}, \mathrm{kg} / \mathrm{d}^{* *}$ & $20.8 \pm 3.4$ & $22.0 \pm 3.3$ \\
$\mathrm{SCM}^{3)}, \mathrm{kg} / \mathrm{d}^{* *}$ & $20.4 \pm 3.2$ & $21.7 \pm 3.3$ \\
pH** & $6.64 \pm 0.09$ & $6.52 \pm 0.09$ \\
Total VFA, mmol/d $l^{* *}$ & $8.59 \pm 0.48$ & $9.43 \pm 0.62$ \\
Molar \% of individual VFA & & \\
Acetic acid & $70.9 \pm 2.0$ & $69.8 \pm 2.9$ \\
Propionic acid & $15.4 \pm 0.6$ & $15.8 \pm 1.1$ \\
Butyric acid & $13.7 \pm 1.8$ & $14.4 \pm 2.1$ \\
A/P & $4.6 \pm 0.3$ & $4.5 \pm 0.5$ \\
\hline 1) SNF : solids-non-fat & & \\
2) 4\% FCM : 4\% fat corrected milk & \\
3) SCM : solids-corrected milk & \\
* and ** indicate statistical significances between \\
ALC3 and BP 3 (P<0.05 and P<0.01, respectively)
\end{tabular}


飼料であると考えられた。

$$
\text { 文献 }
$$

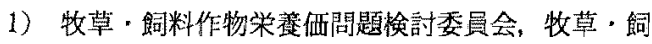
料作物の栄盖価評㑡の手引き. 北農会. 北海道. 1991.

2) Castle, M.E., M.S. Gill and J.N. Watoson, Silage and milk production : a comparison between barley and dried sugar-beet as silage supplements. Grass and Forage Science., 36 : 319-324. 1981.

3) EdWARd, B. and B. RAYBuRn, Variation in neutral detergent fiber intake of Holstein cows.J. Dairy Sci., 76 : 544-554. 1993.

4) Haaksma, J., Feeding value of beet pulp compared to other fodder. Proceedings of International Institute for Sugar-beet Research 45th winter congress, 119-132. 1982.

5）暒川博・大串正明・土屋いつうみ・甘利雅拡・柾 木茂彦，飼料のルーメン内発醉特性の in vitro 評
価法. 日畜会報，64：909-917. 1993.

6) Kelly, P., Sugar Beet pulp A Review. Animal Feed Science and Technology, $8: 1-18.1983$.

7) Miller, T.K., W.H. Hoover, W.W. Poland, Jr, R. W. WOOD and W.V. Thayne, Effects of low and high fill diets on intake and milk production in dairy cows. J. Dairy Sci., 73 : 2453-2459. 1990.

8) National Research Council, Nutrient Requirements of Dairy Cattle. 6th revised ed. 55. National Academy Press. Washington, D.C. 1988.

9）農林水産省農林水産技術会議事務局編，日本標準 飼料成分表. 第 1 版. 中央畜産会. 東京. 1987.

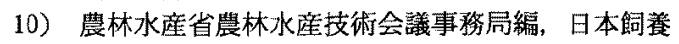
標準・乳牛，第 1 版。中央畜産会. 東京. 1987 .

11) PhatAK, L., K.C. Chang and G. BRown, Isolation and characterization of pectin in sugar beet pulp. J. Food Sci., 53 : 830-833. 1988.

12）吉田 実，畜産を中心とする実験計画法. 第 1 版. 116-124，養賢堂. 東京. 1975 . 


\title{
Feeding Values of Beet Pulp Compared with Corn, Grass Hay and Alfalfa Hay Cube for Dairy Cows
}

\author{
Hiroo Sadoya, Tadashi SATO, Katsusaburo TAnaka \\ and Meiji OKamoto* \\ Research Center, Nippon Beet Sugar Manufacturing Co., LTD, \\ Obihiro-shi 080 \\ * Obihiro University of Agriculture and Veterinary Medicine, \\ Obihiro-shi 080
}

Three experiments with lactating Holstein cows were conducted in order to investigate the effects of substituting beet pulp (BP) for corn (experiment 1), grass hay (experiment 2), and alfalfa hay cube (experiment 3 ) on milk production. Experiment 1 was made using three formula feeds with differing corn content: BP (BP0 100:0, BP25 50:50, BP 50 0:100). Experiment 2 was conducted to examine the effects of the ratio of grass hay to $B P(100: 0,50: 50,0: 100)$ on milk production. Exreriment 3 was conducted to compare alfalfa hay cube with BP. Experiment 1 : When substituting BP for $50 \%$ of corn, milk production decreased slightly, but milk fat increased slightly. Then 4\% FCM and SCM of BP 0 were equal to BP 25. Experiment 2 : Dry matter intake, milk production, milk protein and SNF of cows fed BP were higher than for those fed grass hay. The milk fat of cows fed BP and grass hay was the highest in all treatments. Experiment $3:$ Dry matter intake showed no difference between cows fed $\mathrm{BP}$ and alfalfa hay cube. Milk yield, $4 \%$ FCM and the SCM of cows fed BP increased significantly. Total volatile fatty acid (VFA) in the rumen of cows fed BP significantly increased, but the molar proportion of VFA showed no difference.

Anim. Sci. Technol. (Jpn.) 66 (6) : 540-547, 1995

Key words : beet pulp, corn grain, grass hay, alfalfa hay cube, milk production 